\begin{tabular}{|c|c|c|c|c|c|c|}
\hline \multirow{4}{*}{ Impact Factor: } & ISRA (India) & $=3.117$ & SIS (USA) & $=0.912$ & ICV (Poland) & $=6.630$ \\
\hline & ISI (Dubai, UAE & $=0.829$ & РИНЦ (Russia) & $=0.156$ & PIF (India) & $=1.940$ \\
\hline & GIF (Australia) & $=0.564$ & ESJI (KZ) & $=8.716$ & IBI (India) & $=4.260$ \\
\hline & JIF & $=1.500$ & SJIF (Morocco) & $=5.667$ & OAJI (USA) & $=0.350$ \\
\hline
\end{tabular}

\section{SOI: 1.1/TAS DOI: 10.15863/TAS International Scientific Journal Theoretical \& Applied Science}

p-ISSN: 2308-4944 (print) e-ISSN: 2409-0085 (online)

Year: 2019 Issue: $06 \quad$ Volume: 74

Published: $22.06 .2019 \quad$ http://T-Science.org

SECTION 13. Geography. History. Oceanology. Meteorology.
QR - Issue

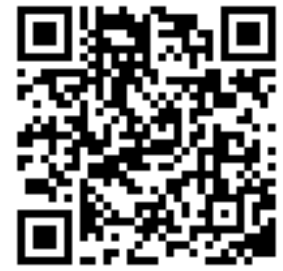

QR - Article

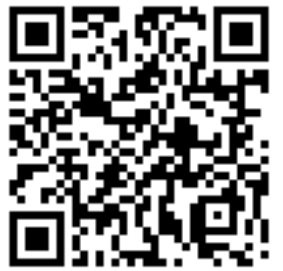

Nargiza Makhsatjonovna Hasanova the regional center of retraining and qualifications of the associate workers of Andizhan region

Teacher, Republic of Uzbekistan

\title{
REQUIREMENT OF SOCIAL AND POLITICAL ACTIVITY OF WOMENS IN MODERNIZATION OF OUR COUNTRY (As an example of Andizhan region)
}

\begin{abstract}
This article explains the importance of women's rights, their place in society, their participation in socio-cultural and spiritual life, the constitutional status of women, their rights and their place in society. In the society, the realization of women's ideas on social justice, equality and stability, the protection of their interests, as well as the promotion of their state policy, have become increasingly widespread in the society, increasing the status of women and implementing large-scale work on this issue the basis of the legal documents.

Key words: State Program, Women, Reform, Law and Legal Acts, Socio-Economic, Andizhan Region, Equality, Gender, Reconciliation, Occupation, Ethics, Principle.

Language: English

Citation: Hasanova, N. M. (2019). Requirement of social and political activity of womens in modernization of our country (As an example of Andizhan region). ISJ Theoretical \& Applied Science, 06 (74), 366-369.

Soi: http://s-o-i.org/1.1/TAS-06-74-44 Doi: crossef https://dx.doi.org/10.15863/TAS.2019.06.74.44
\end{abstract}

... It is inaccessible to measure the place of women in society, and the unique contribution of women to the achievements of Uzbekistan.

Shavkat Mirziyoev

\section{Introduction.}

An appropriate legal and regulatory framework that promotes the equal participation of women in the implementation of democratic reforms and the formation of civil society is being developed and being improved from year to year. In particular, the Constitution of the Republic of Uzbekistan guarantees equality before the law irrespective of gender, race, nationality, language, religion, social origin, beliefs, personality and social status of all citizens [1, p.9]. It is also true that women and men are equal in [2, p.17], in the Citizenship, Family and Employment Codes. In addition, the names of the year and the state programs in our country are connected with our women, increasing the status of women.

Research methods.

From the first years of independence, the realization of the ideas of social justice, equality and stability of all women in the society, and the protection of their interests have risen to the level of state policy. In this regard, the first President of Uzbekistan Islam Karimov stated: "We have to radically change the situation of women in society and in the family, and the attitude of women should serve as a measure of the moral, ethical maturity of our society" [3, p.36]. has given way to practical work in this area. It is in these processes that the development of society is determined by the attitude towards women.

Today, one of the main directions of the state policy of Uzbekistan is to improve the status of women and increase their activeness in the process of implementation of socio-economic reforms. It also protects the rights and freedoms of women. The government's attention to women has grown steadily and has increased the status of women in society, and large-scale work has started on this issue. Many of the 


\begin{tabular}{|c|c|c|c|c|c|c|}
\hline \multirow{4}{*}{ Impact Factor: } & ISRA (India) & $=3.117$ & SIS (USA) & $=0.912$ & ICV (Poland) & $=6.630$ \\
\hline & ISI (Dubai, UAI & $=0.829$ & РИНЦ (Russia & $=0.156$ & PIF (India) & $=1.940$ \\
\hline & GIF (Australia) & $=0.564$ & ESJI (KZ) & $=8.716$ & IBI (India) & $=4.260$ \\
\hline & JIF & $=1.500$ & SJIF (Morocco & $=5.667$ & OAJI (USA) & $=0.350$ \\
\hline
\end{tabular}

laws and legal documents adopted in our country have been the basis for this.

In particular, the Presidential Decree "On Measures for Improving the Role of Women in the State and Social Construction of the Republic of Uzbekistan" as of March 2, 1995, was adopted in accordance with the Decree of the President of the Republic of Uzbekistan of March 17, 1999 "On Additional Measures for the Separation of Social Security of Women" the Decree of the President of the Republic of Uzbekistan "On additional measures to support the activities of the Women's Committee of Uzbekistan" dated May 25, 2004, "On additional privileges for women" The Decree of the Cabinet of Ministers of the Republic of Uzbekistan dated June 10, 1999 № 2326 "On support of proposals for the establishment of Zulfiya State Prize", the Year of the Health of the Mother and Child (2016 - Year of Healthy Child, 2014) Year of the harmonically developed generation, 2001 - Year of Mothers and Children, 2000 - Year of Healthy Generation, 1999 Year of Family, 1998 - Year of the Family), relationships with our women, society, government knowledge, intelligence, phonetics and the bright motto of their confidence in their capacities became a beautiful expression of good deeds.

Respected President of the Republic of Uzbekistan Shavkat Mirziyoev, who has come to the forefront of the country's governance, regarded women's issues as one of the priorities of the state policy and in his greetings on the International Women's Day on March 8, 2017, "Our First President Islam Abduganievich Karimov he emphasized that he had been highly respected, constant attention and caring for his wife and said, "If a woman is happy, family happier, an insight, a lot of fine words and practical guide noted, every society on earth today in connection with the cultural level of its women. This is a fact that does not require proof. We have set the ultimate goal of promoting this large-scale work in our country by following this noble call "[4, p.341-352], emphasizing the importance of women in society.

This has shown that women's empowerment is a more intensive step in society, and that they are more active in raising their role and participation in social processes. During the last period (2016-2019) within the framework of the Decree No. PF-5325 of the President of the Republic of Uzbekistan "On measures to radically improve the activities of the Women's Support and Family Empowerment Center" dated February 2, 2018, 1 decrees, 2 decrees of the President, 6 decisions of the government and 4 decrees. Based on these documents, the Women's Committee and its territorial divisions were established on a completely new basis, with a lack of opportunities and weakened activities. They created additional conditions and opportunities for them to function effectively. At present, more than 10 thousand women with great knowledge and experience are working in this system.

At the regional offices of the Women's Committee were organized "Women Lawyers", "Scientists and Women", "Women's Creations", "Initiative Women", "Women and Health" and "Honorary Women". The contest "Woman of the Year" and "Macro Family". And most importantly, such important measures have been yielding its effect today. For the women who are working on the protection of motherhood and childhood, the education of young people in the spirit of patriotism, the label "Mutabar-ayol" has been established and on the eve of the International Women's Day March 8, 2019, 260 women have been awarded with this award.

As you know, today almost $50 \%$ of the population of our country are women. Of these, about 1,400 women are in government and 17 are senators, 16 are members of the Legislative Chamber of the Oliy Majlis, and 1,757 are members of local councils of people's deputies. The share of women in health and social services is more than 82 per cent, in science, education, culture and arts - 72 per cent (5821861 students currently studying in the field of education, of which $28,416,616$ are $48.8 \%$ Of the 279788 students, 146074 (48.8\%), 442881 of whom are teaching staff, including 311,560 women (70.3\%), agriculture (45\%) and industry (38\%). More than 500 doctors and academicians, thousands of candidates of science are dedicated to the development of our country with their knowledge and talent. Today, 373,500 young people are enrolled in higher education institutions in our country. Of these, 168 thousand 470 $(45.1 \%)$ are girls. In particular, today about half of the Andijan region's population is more than 1.5 million women. About 9,000 women are working in managerial positions in enterprises and organizations. The Association "Science and Women" has 150 scientists, 19 of them are doctors of science and 131 are candidates of science.

Thousands of women, who have earned a reputation for their self-sacrificing work, their great achievements, active participation in government and public affairs, their wellbeing qualities, and their commitment to science, education, healthcare, culture and arts - The fact that the women's organization has shown itself during the years of independence shows the growing role of women in society.

During the years of independence, more than 2,818 women have been honored by the state and our people, who have been honored with high state awards, "Hero of Uzbekistan", "Honored Art Worker of Uzbekistan", "People's Poet of Uzbekistan" the People's Artist of the Republic of Uzbekistan, has earned high awards, medals and awards, and has earned a great deal of achievements in science, literature, culture, arts, sports and public affairs, about 300 talented young people up to thirty The winners of the Zulfiya State Prize were awarded with state prize 


\begin{tabular}{|c|c|c|c|c|c|c|}
\hline \multirow{4}{*}{ Impact Factor: } & ISRA (India) & $=3.117$ & SIS (USA) & $=0.912$ & ICV (Poland) & $=6.630$ \\
\hline & ISI (Dubai, UAE & $=0.829$ & РИНЦ (Russia & $=0.156$ & PIF (India) & $=1.940$ \\
\hline & GIF (Australia) & $=0.564$ & ESJI (KZ) & $=8.716$ & IBI (India) & $=4.260$ \\
\hline & JIF & $=1.500$ & SJIF (Morocce & $=5.667$ & OAJI (USA) & $=0.350$ \\
\hline
\end{tabular}

named after Zulfiya (nowadays the winners receive many benefits, including the Ministry of Finance of the Republic of Uzbekistan, each of the winners of Zulfia State Prize is awarded a 50-fold minimum wage, graduates of secondary special and professional educational institutions of Zulfiya State Prize, and bachelor students - higher education institutions the adoption of state grants without the entrance exams in the direction and specialty of the bee's magistracy is surely the best gift to our girls).

At the initiative of the head of state, the cooperation between the Women's Committee of Uzbekistan and political parties in our country has been intensified, and it is worth noting that a reserve of about 3,000 women's cadres is formed. At the same time, a system of preparation of social activist women to leadership positions, their training, qualification upgrading is being created. Today, women constitute $30 \%$ of the deputies' corps, which shows the growing political consciousness and level of women in the past two years.

The consolidation of the institution of the family in the past period has become a state policy in our country, and the important document - the Concept of strengthening the institution of the family in the Republic of Uzbekistan. In order to implement this concept, the Center for Scientific and Practical Research "Family" was reorganized.

A comprehensive system of studying the family problem, creating a new system that analyzes the current situation, monitors and evaluates and enhances family well-being through scientific research. On March 7, 2019 the Decree of the President of the Republic of Uzbekistan "On Measures to Further Enhance the Guarantees of Women's Labor Rights and Support the Entrepreneurial Activity" was adopted (the Decree came into force from March 9, 2019). This decree establishes completely new guarantees for the rights of women in the field of labor and pension, as well as gender equality. Prohibitions and restrictions on women's labor are abolished. Women's Entrepreneurship Centers are organized to help women to create their own businesses, help them prepare business ideas, help them with long-term child rearing, and help women with difficult economic conditions.

Today, there is a great deal of issues that need to be solved, with no matter how high the focus is on opportunities and women. These include women's employment and health and family relationships. A number of positive steps have been taken to address these problems and gradually find their solution. President of the Republic of Uzbekistan Shavkat Mirziyoyev also noted in his reference to the Oliy Majlis that "... social support of the state should be further strengthened today. Regardless of the practical measures taken in the current year, it is sad that there are more than 13,000 women still living in difficult living conditions and unemployed. The Ministry of Labor and Employment and the Women's Committee should work together with regional khokimiyats in a month to develop a program to support such women. "[5] The Central Bank, the Karakalpakstan, the provinces and the city of Tashkent, 1,600 women were given the task to provide cheap housing on favorable terms.

Over the past two years, the volume of loans allocated to women for entrepreneurship and the development of family entrepreneurship has doubled. In 2014-2016, commercial banks issued 3 trillion 800 billion soums of credits to entrepreneurs, while in 2018 this figure was 3 trillion 361 billion soums. In the State Program 2019 it is planned to allocate 100 billion soums for the further development of women entrepreneurship (item 169). Only 2018 in Andijan region, 199 million 613 million soums have been allocated to 2,000 860 women entrepreneurs and more than 50 percent of women are pursued [6].

In addition, a system of preferential lending was introduced at the expense of newly established Women and Family Welfare Fund, with a 7\% annual payment. In 2018, 50 billion sums will be allocated for these purposes. This contributes to the creation of the necessary conditions for women to engage in family, cemetery, home-work and households, without distinction from family and children. At the initiative of the Women's Committee in 2018, more than 2,000 smaller workshops were set up, with about 18,000 women being employed. In Andizhan, Namangan and Ferghana regions, in cooperation with the Hunarmand Association, the employment of unemployed women has been secured on the basis of the "Teacherapprenticeship" system. At present, the work on the application of this experience in all regions is underway. In particular, 2,743 women in Andijan Province were involved in vocational training in various fields [7].

In order to safeguard the rights of women, 155 centers for the rehabilitation and adaptation of persons suffering from violence have been set up in the regions, "hot lines". Particular attention was paid to the new policy issue in our country's politics, an effective system of house-to-house visits, study of the socio-cultural environment and solution of existing problems were created in our country. Under this system, the problems of more than 47 thousand 690 people in difficult conditions in 2018 and 13 thousand 344 disabilities have been studied on the spot. As a result of the measures taken, more than 14750 people were provided with medical aid, 13,636 were employed, and 24,660 were provided with material assistance of 21 billion 540 million soums. About 4,000 cheap housing units were provided to these seniors who needed housing, and the state paid their initial costs [8]. In Andizhan region, 459 families were provided with housing, including women with disabilities and those with severe social problems, 


\begin{tabular}{|c|c|c|c|c|c|c|}
\hline \multirow{4}{*}{ Impact Factor: } & ISRA (India) & $=3.117$ & SIS (USA) & $=0.912$ & ICV (Poland) & $=6.630$ \\
\hline & ISI (Dubai, UAI & $=0.829$ & РИНЦ (Russia & $=0.156$ & PIF (India) & $=1.940$ \\
\hline & GIF (Australia) & $=0.564$ & ESJI (KZ) & $=8.716$ & IBI (India) & $=4.260$ \\
\hline & JIF & $=1.500$ & SJIF (Morocco & $=5.667$ & OAJI (USA) & $=0.350$ \\
\hline
\end{tabular}

including low-income families with low income families and children from low-income families. Approximately one thousand women were employed at sewing shops around these settlements. In 2019, it is envisaged to employ 1,500 women with housing and more than 13,000 women in this category [9]. All of these are the most important results of the implementation of the issues of improving women's living and living conditions, which led to the joy of many households. Nowadays, systemic measures are being taken to social rehabilitation of women, who are freed from solitary confinement and imprisonment with persons who are primarily ill-intentioned in the issue of early detention of women. Additionally, special attention is given to providing practical help to more than 3,000 women and women who have been expelled from the suspected list of suspected religious extremists. At the same time, the representatives of Women's Committees participate in public hearings in order to protect the rights and interests of women in courts. As a result of this new practice, in the year 2018, 893 women were convicted and sentenced to imprisonment.

In order to reduce the number of crimes resulting from family-related problems, 10,145 foster families were prevented and $71 \%$ were displaced. It is important to emphasize that, as a result of the joint efforts of women, makhallas, prophylactic inspectors and measures taken, the crime rate among women has decreased by $34 \%$ in 2018 [10]. In addition, a memorandum was signed between the Supreme Court and the Women's Committee, and initiated the interview with the Women's Committee and the findings of the ruling. By the end of 2018, about 26,000 families were separated from the divorce. More than 36,500 children were prevented from losing parental authority. All this indicates that women's movement in the country has great potential and perspective.

\section{Conclusion.}

In summary, today, the tasks set by the State Program of Action and the President of the Republic of Uzbekistan being widely supported by the efforts of women in various fields of activity in Uzbekistan.

In recent time in Andizhan region, women's committees, district and city systems, primary organizations raise employment of women through social and political activism, family business, entrepreneurship, craftsmanship, and home-based work to women and families with disabilities with a special emphasis.

\section{References:}

1. (2017). The Constitution of the Republic of Uzbekistan. Article 18 (1 Point), Section V, Part II. (p.9). Tashkent: Uzbekistan.

2. (2017). The Constitution of the Republic of Uzbekistan. Article 46, Section X, Part II. (p.17). Tashkent: Uzbekistan.

3. Karimov, I. A. (1996). Homeland is sacred. Volume 3: "Uzbekistan", page 36.

4. Mirziyoev, S. M. (2018). We will continue our path of national development with determination and bring it to a new level.1 Vol. (pp.341-352). Tashkent: Uzbekistan.
5. (2018). Decree of the President of the Republic of Uzbekistan Shavkat Mirziyoev addressed to the Oliy Majlis on December 28, 2018.

6. (2019). Andizhonnoma, 2019 iil 6 March. №1920.

7. (2018). The Xalq so'zi, November 17, 2018.

8. (2018). The Xalq so'zi, November 21, 2018.

9. (2019). The Xalq so'zi, December 10, 2019.

10. (2019). Andizhonnoma, December 16, 2019. 